UDC 631.62

\title{
THE STATE OF DRAINAGE SYSTEMS IN THE NORTHERN PART OF LVIV REGION
}

\author{
Andriy Mykhnovych \\ Ivan Franko National University of Lviv, \\ P. Doroshenko St., 41, UA - 79007 Lviv, Ukraine, \\ e-mail:2andira@ukr.net
}

\begin{abstract}
Recent land use and renaturalization problems on the drained areas testify about considerable decrease of biological producing ability of the soils during last decades mainly due to ineffective using of the drained areas and unsatisfactory technical state of the drainage systems. The swamped and overwatered lands in some districts of Lviv region reach $80-90 \%$ of the territory and occur as large solid areas in the river basins. For today, most of the drainage systems are characterized by unsatisfactory technical state and lose or have lost the water regulating ability as agricultural importance. Therefore, the investigations of the present land-reclamation, ecological and technical state of drainage systems and drained areas with identification of most priority areas for wetlands renaturalization is actual and urgent scientific and practical task. Its solution is impossible without substantiation of the scientific concept and methods of investigations. The drainage systems of the Polissian part of Lviv region are studied. The objective is evaluation of the drainage systems state, ascertaining of the drained areas adaptability and service ability to renaturalization as well as substantiation and adaptation of the methods of the state evaluation. The paper deals with the history of drainage systems establishing, exploitation and investigations in the region with the aim of ecological state improving. The main characteristics of the drainage systems and their monitoring network are presented. The methods and criteria of meliorative state analysis are characterized. The impact of dewatering upon groundwater levels, the seasonal variation of groundwater level and the meliorative state of three etalon drainage systems have been analyzed.

Key words: drainage systems, dewatering, land-reclamation, ecological and technical state, renaturalization.
\end{abstract}

Drainage is eliminating of excessive water from a soil, the type of melioration. In Ukraine, two types of drainage are used: drainage by the open canals for preliminary dewatering of bogs, forests, meadows, pastures and hayfields; draining by the closed dewatering systems (regulated network of drains and closed water collectors). This type of engineering is more perfect, durable and inserted into the soil [11]. By flowing into catchwaters the drainage systems are divided on self-flowing and polder (with water pumping). By the character of influence on the drained area water regime these systems are divided on oneside effect (only dewatering) and two-side effect (with interruption and redistribution of excessive water and its replenishment in a soil during dry periods) [11].

The main methods of drainage are: Acceleration of the surface and ground water runoff; Lowering of the ground water level; Preventing and blocking of the ground and surface waters inflow from the catchment basin; Increasing of water pressure in the artesian water horizons; Protecting against flooding and regulating of floods dates and duration. Due to

(C) Mykhnovych A., 2018 
nature conditions diversity and different causes of excessive watering usually a few methods are combined, especially in case of mixed alimentation. In addition, it concerns to the floodplains with complex water-air regime formed under different factors.

Analysis of the land use and renaturalization problems on the drained areas testifies about considerable decrease of biological producing ability of the soils during last decades mainly due to ineffective using of the drained areas and unsatisfactory technical state of the drainage systems. As the main effects podzolization, carbonization, superdrying of the soils, peat inflaming, deflation, secondary swamping, succession, depletion of plant species diversity and monoculture domination are called [1, 4, 11, 14].

On the strategic level, it is necessary to develop the program of drained areas inventory, their using effectiveness assessment, ecological monitoring and the general scheme of the wetlands and peatbogs renaturalization [3].

The subject of inquiry is drainage systems of the northern (Polissia) part of Lviv region. The objective is evaluation of the drainage systems state, ascertaining of the drained areas adaptability and service ability to renaturalization as well as substantiation and adaptation of the methods of the state evaluation.

The history of the water management and drainage in Lviv region starts since XVIII century. Four stages are considered usually: Austro-Hungarian, Polish, Soviet and Ukrainian. All of them are characterized by different scales of performed work and different level of the constructions technical perfection.

Austro-Hungarian period are characterized by using of open channels systems and agromelioration on the local scale. The first area, which was drained by open channels network, is the Yarychika river valley (the tributary of the Poltva river) between Hriada and Yarychiv villages. Since the middle of XIX century in the Male Polissia the river regulation with floodplains dewatering by the open drainage network was put into practice. The projects of the Western Bug river regulation were developed in 1846, 1862, 1878 [3]. In first half of XIX century drainage by the open canals network realized par excellence on the private acres of the big landlords and were planed and managed by the engineers of the agrarian societies or regional water management authorities. At the same time the drain-pipes and closed drains were started to use in the large fields of rich land owners.

In 1879, the Regional Bureau of Melioration was founded in Lviv that was responsible for the strategy and coordination of land-reclamation as well as river regulation and flood protection. Drainage methods in the Western Bug, Styr rivers at that time consist of three combined work: field dewatering, silting and colmatage of peatbogs, water intake rivers regulation and flood protection [3].

The first researches associated with the melioration problems, especially drainage influence on the neighboring areas concern the end of century. Such investigations were carried out by the engineer Y. Blauth on the research sites in the Styr river (1897-1898) and the Western Bug river (1900-1903).

Between the World wars, in 1920-1930 reconstructions of the water engineering and building of the new drainage systems were done including the "Bolotnia" system (7 410 ha), Poltva system (6 490 ha), New-Yarychiv (7 870 ha) and Bilostots'ka (5 260 ha). The floodplain areas were mostly drained by the open channels network. The main aim of these systems was accelerating dewatering after the floods and spring-floods.

After World War II, the inventory works on meliorated areas and hydrotechnical constructions, their cadastre, theory and practical experience systematization were started [3]. 
In 1954, the Lviv Regional Department of Water Management has been founded. In 1960-s the large drainage systems were built in the Western Bug and Styr catchments applying the new methods of engineering calculations of hydrological effect of a drainage network. These works were associated with detail investigations of physical, physic-chemical and waterphysical features of the soils and their characteristics.

Hydrological and hydrogeological observations on the network of gauging stations bore holes and wells were carried out in all natural regions of the Male Polissia. The results of research have been published in the scientific papers of B. Kozlovs'kyi, Y. Bilous, K. Tereshchenko, V. Burdan, N. Kohut and others [8, 10].

The problems of a drainage system state analysis and its improvement are considered in the papers of K. Tereshchenko (1969), V. Aleksiyevskiy (1980), B. Kozlovs'kyi (19872005). The influence of the drainage on the environment is considered in the papers of B. Maslov (1977, 1985), I. Minaev (1985), B. Kozlovs'kyi (1987) and others [8, 10, 11].

During the period of 1950-1992 the total drained area in Lviv region has increased twice. In 2009, the largest drainage systems in the studied area were Vereshchytsia (19 $100 \mathrm{ha}$ ), Zheldets' (16 300 ha), "Solokia" (16 236 ha) [3].

The actual period is characterized by the endeavor to provide the accordance of water engineering and management with nature protection on the base of the catchment approach and Water Framework Directive. There is essential scientific-methodological base for the drained areas state assessment and their zoning by hydro-meliorative and ecologicgeographical states. The main aim of these works is to determine the practicability of continuous exploitation, reconstruction of the drainage system or renaturalization of the drained peatbogs and nature conservation measures. The scientific works in meliorative hydrogeology concerns to ecological problems like anti-erosion protection, wetlands renaturalization, biotopes conservation, biodiversity renewing, flood risk mitigation etc.

The groundwater monitoring within the drained areas is carried out by the Hydrogeologicmeliorative Expedition (incorporated with the State Water Resources Management Agency). These monitoring stations and points consist of bore holes and geological profiles and observe the water levels, temperature and hydrochemical regime within the drainage systems. Before 1990, the total amount of the observation bore holes was 874. At the beginning of 1990 -s the observations were stopped because lack of money. Recently 2/3 of points is destroyed or need to be repaired. Now such observations are carried out only within the 11 etalon drainage systems. Three of them are located in the Male Polissia (Solokia, Bolodurka and Nedilchyna systems) [3]. The list of the drainage systems and the actual monitoring network is presented in the table 1 and 2.

Important precondition for wetlands and peatbogs renaturalization is zoning of the drained areas by hydrologic-meliorative and ecological states and also drainage systems technical state to ascertain their practicability for follow exploitation, reconstruction, renovation or renewal of natural biogeocoenoses, landscape and biological diversity enhancing and nature conservation.

Degradation degree of the drainage systems depends on the time past since their constructing or last renovation. The first quantitative attribute of the drainage system degradation degree is ratio between the amount of disabled and obsolete hydrotechnical constructions and their total amount. Nevertheless, it is necessary to note that high rate of the technical degradation does not cause flooding or high groundwater level every time. However, drainage system degradation degree evaluated by only the technical parameters can 
inadequately reflect hydrologic-meliorative state of the drained land and opposite. It is important to differentiate the drainage system technical degradation degree and the drained areas degradation degree, which is evaluated by swamping and flooding rate and the time of dewatering (water runoff) (so called degree of hydrogeologic-meliorative degradation). This feature should have straight impact upon water pollution.

Therefore the next important research task is evaluation of recent hydrogeologicmeliorative state of the drained territory which is based on the observations on the bore-holes, wells and gauging stations network.

The synthesized degree of the drainage system obsolescence can be defined with the help of water balance calculations. The tendency of decreasing ground water inflow to the channels network testifies about obsolescence and disabling of the drainage system. Due to water level increase in the channels and rivers and prolongation of ground waters alimentation the intensive silting and overgrowing of the riverbeds and channel are observed. These processes delay the water cycle, causes decreasing of low-water period and ground water outflow, and overall recession of area dewatering.

So assessment of the drainage systems degradation level can be done by three expressive criteria: ground water level regime (measured on the observation bore-holes and wells network), duration of surface water outflow and the unit discharge (ascertained by the dates of high water levels in open channel network and hydrological calculations), share of the areas with secondary swamping or irregular water distribution (determined by the ratio between negative and positive values (the method of balance), identifying of hydrophytes plants distribution as indirect feature, wetland areas increasing in a catchment basin determined the remote sensing methods). These works also have to be included into the tasks of the drainage systems state analysis.

Monitoring network on the etalon drainage systems of Lviv region

Table 1 оніторингов мереж ет лонних осушних систем ьвівщини

\begin{tabular}{|c|c|c|c|c|c|c|c|c|}
\hline \multirow{2}{*}{ № } & \multirow{2}{*}{$\begin{array}{c}\text { Name } \\
\text { of the system }\end{array}$} & \multirow{2}{*}{$\begin{array}{c}\text { Number } \\
\text { of cross- } \\
\text { section }\end{array}$} & \multicolumn{4}{|c|}{$\begin{array}{c}\text { Amount of bore holes } \\
\text { (total/working bore holes) }\end{array}$} & \multirow{2}{*}{$\begin{array}{l}\text { Amount of } \\
\text { points for } \\
\text { ground } \\
\text { sampling }\end{array}$} & \multirow{2}{*}{$\begin{array}{c}\text { Start of } \\
\text { obser- } \\
\text { vations }\end{array}$} \\
\hline & & & $\begin{array}{c}\text { cross- } \\
\text { section } 1 \\
\end{array}$ & \begin{tabular}{|c|} 
cross- \\
section 2 \\
\end{tabular} & $\begin{array}{c}\text { cross- } \\
\text { section } 3\end{array}$ & Total & & \\
\hline 1 & Bolodurka & 2 & $10 / 7$ & $11 / 9$ & - & $21 / 16$ & 4 & 1987 \\
\hline 2 & Solokia & 3 & - & - & - & $52 / 40$ & 5 & 1986 \\
\hline 3 & Spasivka & 2 & $8 / 6$ & 11 & - & $19 / 17$ & 4 & 1986 \\
\hline 4 & Vyshnia & 2 & $8 / 4$ & 5 & - & $13 / 9$ & 4 & 1987 \\
\hline 5 & Hnyla Lypa & 2 & $4 / 3$ & $12 / 11$ & - & $16 / 14$ & 4 & 1986 \\
\hline 6 & Stavchanka & 2 & 16 & $7 / 5$ & - & $23 / 21$ & 4 & 1986 \\
\hline 7 & Zhyzhava & 2 & $9 / 7$ & 11 & - & $20 / 18$ & 4 & 1986 \\
\hline 8 & Bystrytsia & 2 & $14 / 12$ & $15 / 12$ & - & $29 / 24$ & 4 & 1986 \\
\hline 9 & Bolozivka & 3 & 7 & 9 & $11 / 10$ & $27 / 26$ & 6 & 1987 \\
\hline 10 & Nedilchyna & 2 & 11 & - & $12 / 11$ & $23 / 22$ & 4 & 1986 \\
\hline 11 & Domazhyr & 2 & $7 / 6$ & $7 / 5$ & - & $14 / 11$ & 4 & 1986 \\
\hline & Total & 24 & $94 / 79$ & $88 / 78$ & $23 / 21$ & $257 / 218$ & 48 & \\
\hline
\end{tabular}


ISSN 2078-6441. Вісник Львівського університету. Серія географічна. 2018. Випуск 52

Table 2

Drainage systems of the Polissia in Lviv region сушні системи олісся у меж х ьвівської обл сті

\begin{tabular}{|c|c|c|c|c|c|c|}
\hline № & $\begin{array}{c}\text { Name } \\
\text { of the system }\end{array}$ & District & $\begin{array}{c}\text { Total } \\
\text { area, ha }\end{array}$ & \begin{tabular}{|c|} 
Closed \\
drainage, ha
\end{tabular} & $\begin{array}{c}\text { Year of } \\
\text { construction }\end{array}$ & Reconstructions \\
\hline 1 & 2 & 3 & 4 & 5 & 6 & 7 \\
\hline 1 & Novo-Ukrains'ka & Sokal & 2818 & 1910 & 1965 & 1981-1987/ 1991 \\
\hline 2 & $\begin{array}{l}\text { Velyko- } \\
\text { Mostivs'ka }\end{array}$ & Sokal & 1344 & 1071 & 1965 & 1982-1987 \\
\hline 3 & Nyzhnio-Buz'ka & Sokal & 3450 & 3058 & 1965 & 1981-1984/1986 \\
\hline 4 & Spasivka & Sokal & 2490 & 570 & 1968 & $1978 / 86 / 89$ \\
\hline 5 & Hatkivs'ka & Sokal & 1615 & 940 & 1971 & $1978 / 81$ \\
\hline 6 & Bilostots'ka & Sokal / Radekhiv & 9387 & 6649 & $1965-1972$ & 1980-84/1987-89 \\
\hline 7 & Solokia & Sokal & 16236 & 7755 & 1972 & 1983-1989 \\
\hline 8 & Bolotnia & Sokal / Zhovkva & 12243 & 6501 & 1975 & 1981-84/1986-92 \\
\hline 9 & Rata & Sokal / Zhovkva & 5741 & 2560 & 1969-1971 & $1984 / 1986$ \\
\hline 10 & Zheldets'ka & $\begin{array}{l}\text { Sokal / Zhovkva / } \\
\text { Kamyanka-Buz'ka }\end{array}$ & 16387 & 14337 & 1963-1967 & $\begin{array}{c}1980-1984 / 1988- \\
1991 / 1997\end{array}$ \\
\hline 11 & Rakytnians'ka & Sokal & 3440 & 2796 & 1968 & $1972 / 80 / 86$ \\
\hline 12 & Voluts'ka & Zhovkva & 747 & 640 & 1970 & 1980 \\
\hline 13 & Moshchans'ka & Zhovkva & 5078 & 3297 & 1930 & 1970 \\
\hline 14 & $\begin{array}{l}\text { Skvariavo- } \\
\text { Soposhyns'ka }\end{array}$ & Zhovkva & 9842 & 7692 & 1965 & \\
\hline 15 & Balandyns'ka & Zhovkva & 2699 & 2292 & 1957 & \\
\hline 16 & Zhovkivs'ka & Zhovkva & 356 & 349 & 1961 & \\
\hline 17 & Dereven'kivs'ka & Zhovkva & 4747 & 3401 & 1958 & \\
\hline 18 & Butyns'ka & Zhovkva & 3142 & 1390 & 1960 & \\
\hline 19 & Bila & Zhovkva & 7432 & 5770 & 1960 & \\
\hline 20 & Kholuivs'ka & Kamyanka-Buz’ka & 824 & 785 & 1975 & $1983 / 86 / 87$ \\
\hline 21 & Serednio-Buz'ka & Kamyanka-Buz’ka & 5826 & 5740 & 1966 & $1989 / 91$ \\
\hline 22 & Batiuchka & Kamyanka-Buz’ka & 1900 & 1892 & 1961 & $1973 / 77 / 82 / 83 / 95$ \\
\hline 23 & Horpyns'ka & Kamyanka-Buz'ka & 4848 & 4755 & 1986 & $1988 / 90 / 91$ \\
\hline 24 & Streptivs'ka & $\begin{array}{c}\text { Kamyanka-Buz'ka } \\
\text { / Bus'k }\end{array}$ & 1238 & 1216 & 1968 & 1988/90/91 \\
\hline 25 & Rakobovtivs'ka & Bus'k & 191 & 191 & & \\
\hline 26 & Ripnivs'ka & Bus'k & 1497 & 732 & 1971 & \\
\hline 27 & Volyts'ka & Bus'k & 1270 & 129 & 1959 & \\
\hline 28 & \begin{tabular}{|l} 
Pobuzhano- \\
Yablunivs'ka
\end{tabular} & Bus'k & 2695 & 2296 & 1958 & \\
\hline 29 & Rakytnians'ka & Bus'k & 2817 & 2378 & 1959 & $1979 / 82$ \\
\hline 30 & Slotvyns'ka & Bus'k / Zolochiv & 6387 & 4951 & 1955 & 1987 \\
\hline 31 & Dumnens'ka & $\begin{array}{l}\text { Kamyanka-Buz'ka } \\
\text { / Bus'k / Zhovkva }\end{array}$ & 3896 & 2705 & 1957-1961 & $1976 / 79 / 82 / 85 / 86 / 92$ \\
\hline 32 & Yarychivs'ka & $\begin{array}{c}\text { Kamyanka-Buz'ka } \\
\text { / Bus'k / Zhovkva / } \\
\text { Pustomyty }\end{array}$ & 7339 & 4374 & 1966 & $\begin{array}{c}\text { 1971/72/73/74/76/ } \\
83 / 84 / 85 / 87 / 88\end{array}$ \\
\hline 33 & Nedilchyns'ka & Zhovkva & 1767 & 969 & & \\
\hline 34 & Bilkivs'ka & Pustomyty & 9803 & 6889 & & \\
\hline
\end{tabular}



ISSN 2078-6441. Вісник Львівського університету. Серія географічна. 2018. Випуск 52

\begin{tabular}{|c|c|c|c|c|c|c|}
\hline \multicolumn{7}{|c|}{ Continuation of the table 2} \\
\hline 1 & 2 & 3 & 4 & 5 & 6 & 7 \\
\hline 35 & Poltvyns'ka & \begin{tabular}{|c|} 
Bus'k / Zolochiv / \\
Pustomyty \\
\end{tabular} & 12181 & 8684 & $1936 / 1956$ & $1958 / 80 / 84 / 89$ \\
\hline 36 & $\begin{array}{l}\text { Buh- } \\
\text { Zolochivs'ka }\end{array}$ & Zolochiv & 2352 & 1100 & 1969 & 1980 \\
\hline 37 & Kurovyts'ka & Zolochiv & 4426 & 3839 & 1972 & \\
\hline 38 & Yaktorivs'ka & Zolochiv & 2947 & 2650 & 1972 & \\
\hline 39 & Holohirs'ka & Bus'k / Zolochiv & 7453 & 6398 & 1954-1958 & $1976 / 89$ \\
\hline 40 & Verkhnio-Buz'ka & Zolochiv & 1906 & 1021 & 1975 & \\
\hline 41 & Zolochivs'ka & Zolochiv / Bus'k & 3616 & 2644 & 1965 & $1967 / 76 / 80$ \\
\hline 42 & Slonivs'ka & Brody & 2506 & 36 & 1971 & \\
\hline 43 & Bolodurs'ka & Brody & 3869 & 1165 & 1968 & \\
\hline 44 & Ostrivs'ka & Radekhiv & 4857 & 1777 & 1964 & $\begin{array}{c}1971 / \\
74 / 76 / 86 / 88 / 89\end{array}$ \\
\hline 45 & Pusta & Bus'k & 3154 & 2685 & 1960 & $1987 / 88$ \\
\hline 46 & Chinyz'ka & Bus'k & 2924 & 1066 & 1959 & 1987 \\
\hline 47 & Berezivs'ka & $\begin{array}{l}\text { Kamyanka-Buz'ka } \\
\text { / Radekhiv/ Bus'k }\end{array}$ & 2562 & 1347 & & \\
\hline 48 & Pokrova & Bus'k / Brody & 4594 & 2580 & 1964 & 1968 \\
\hline 49 & Zabolotsivs'ka & Brody & 1331 & 1093 & 1970 & \\
\hline 50 & $\begin{array}{l}\text { Verkhnio- } \\
\text { Styrs'ka }\end{array}$ & Brody / Bus'k & 4445 & 713 & 1971 & 1977 \\
\hline 74 & Loshchivs'ka & Radekhiv & 980 & 822 & & \\
\hline 77 & Viatyna & Brody & 452 & 178 & 1977 & \\
\hline 78 & Radostavka & $\begin{array}{c}\text { Radekhiv / Brody / } \\
\text { Bus'k }\end{array}$ & 2087 & 1340 & $1974-1975$ & 1978 \\
\hline 79 & Sudylivs'ka & Radekhiv & 2543 & 1718 & $1975-1980$ & $1982 / 84 / 85$ \\
\hline 81 & Kamyans'ka & Kamyanka-Buz'ka & 4405 & 4405 & 1977 & $1979 / 80 / 81 / 83 / 88$ \\
\hline 82 & Rudka & Radekhiv & 804 & 592 & 1976 & $1981 / 82 / 85$ \\
\hline 83 & Maidanivs'ka & Radekhiv & 1899 & 1344 & 1975 & $1978 / 80 / 84$ \\
\hline 86 & Hlynians'ka & Zolochiv & 2505 & 2065 & 1980 & \\
\hline 91 & Sokolians'ka & Bus'k & 461 & 439 & 1971 & $1988 / 89$ \\
\hline
\end{tabular}

Next stage of research is assessment of ecological and biological values of the lands, biological and landscape diversity rate, degree of degradation and manmade changes in biogeocoenoses, assessment of the practicability of its renewal. These tasks allow evaluating the wetlands renaturalization possibility.

According to the scheme of physical-geographic zoning of Ukraine, the physicalgeographic region Male Polissia with the Polissia lowland belongs to the Polissia flat-wavy low mixed forest province that is part of Eastern-European Plain [15]. The significant particularity of this natural region is alternate of the river valleys with slow water runoff of Polissia type (like Western Bug, Styr rivers with their tributaries) with the flat swamped denudation interfluves composed of the Cretaceous deluvium and covered by alluvialwashout sands, loamy sands and peats of different thickness. Swamping is caused by low surface inclination, chalk-marl bedrock deposits characterized by low filtration ability.

The river valleys of the Male Polissia are formed in the marls of Cretaceous period, limestones, sandstones and sands of Miocene, in glacial and fluvio-glacial detritus-gravelclay and sand sediments of the Lower Pleistocene. The sediments of Middle and Upper 
ISSN 2078-6441. Вісник Львівського університету. Серія географічна. 2018. Випуск 52

Pleistocene and Holocene compose the relief forms. The river valleys cross two geomorphologic subregions of Volynian-Podillia highland: structural-denudational plateau Podillia in headwaters and aeolian-denudational plain Male Polissia [13].

The main river of the region is Western Bug that passes Male Polissia - area with many meadows and bogs as well as the hills covered by loesses. Here the river is meandering in north-west direction and is characterized by slight inclinations, high meandering and furcation, high canalization, water-divide lines are feebly marked and often are crossed by drainage canals. In central and lower parts the river valley width is $40-75 \mathrm{~m}$, locally up to $100 \mathrm{~m}[2]$.

The relief forming here was disturbed by human impact especially in second half of XX-th century - the period of intensive melioration systems constructing and collective agricultural land use with intensive deforestation. In this period the small rivers and streams received 200-500 t/ha sediments per one year. As the result many streams and ponds were silted, the thickness of river bed and floodplain alluvium increased $0.5-1.5 \mathrm{~m} \mathrm{[6].} \mathrm{At} \mathrm{the}$ beginning of XX-th century the drainage systems constructing was started by straightening and deepening of the Bug river bed. In the soviet period, drainage systems were constructed on the terraces of the river valleys. Drainage became the main factor of other environmental components changes in the catchment - the so-called "chain reaction" of unforeseen ecosystems changes has been started [6].

The climate of studied area is temperate and characterized by soft winters, narrow differences between winter and summer temperatures, high precipitation. The moisture coefficient is 1.1 [12]. The coldest month is January $\left(-4.1^{\circ} \mathrm{C}\right.$ in Kamianka Buz'ka). The warmest month is July $\left(+17.9^{\circ} \mathrm{C}\right.$ in Kamianka Buz'ka). Absolute minimums of air temperature can reach $-28{ }^{\circ} \mathrm{C}$ and maximum is $35^{\circ} \mathrm{C}$ (near Kamianka Buz'ka) [5]. According to the Lviv Hydrogeological-meliorative Expedition the year sum of precipitation in Male Polissia fluctuates between $641 \mathrm{~mm}$ (in Bus'k), 644 mm (in Kamianka Buz'ka), 632 mm (Zhovkva), $603 \mathrm{~mm}$ (Rava-Rus'ka). The smallest sums are in Sokal region (566 mm). About $70-75 \%$ of precipitation is formed in warm period (table 3 ).

Table 3

Meteorological conditions of the studied area етеорологічні умови н досліджув ній території

\begin{tabular}{|c|c|c|c|}
\hline \multirow{2}{*}{ Parameter } & \multicolumn{3}{|c|}{ Etalon drainage system } \\
\cline { 2 - 4 } & Solokia & Nedilchyns'ka & Bolodurs'ka \\
\hline Precipitation, mm/year & 651 & 593 & 690 \\
\hline Average air temperature, $^{\circ}$ & 7.7 & 8.1 & 8.0 \\
\hline
\end{tabular}

Annually 160-185 days with precipitation $>0.1 \mathrm{~mm}$, including 95-110 days with $>1 \mathrm{~mm}$ precipitation can be observed. Once per year the rain with $30 \mathrm{~mm}$ occurs. Rains with $20 \mathrm{~mm}$ are observed three times/year. Maximal rain intensity is higher than $4 \mathrm{~mm} /$ minute [12]. Average evaporation is $560 \mathrm{~mm}$ (in winter $29 \mathrm{~mm}$, spring - 182, summer - 261 and autumn $80 \mathrm{~mm})$. Relative humidity is highest in autumn and winter (80-85\%), and lowest in spring $(48-54 \%)$.

The snow cover is very unstable. Maximal thickness is formed on February. The average parameters change from $7-10 \mathrm{~cm}$ on the closed areas to $30-110$ on opened areas. The average maximal water amount in snow cover is $34 \mathrm{~mm}$. 
According to geobotanical zoning of Ukraine, the study area is located in European deciduous region, Eastern-European province. Swamps are seen in the river valleys and belong to eutrophic herbaceous. Meadow vegetation occurs on the floodplains of small rivers (true meadows) as well as on the hill slopes of southern, western and northern exposition. According to M. Zahuls'kyi, on the slopes the communities of Poeta angustifoliae, Cariceta montanae dominate [15]. Boggy vegetation in Voroniaky has islands distribution and eutrophic-mesotrophic character. Bog fragments are on the different phases of postmeliorational transformation. The massive of Western-European carbonate bogs is between villages Verkhobuzh, Koltiv, Kruhiv in the boggy part of upper Bug river floodplain. There are communities with Cladium mariscus domination (between Verkhobuzh and Kruhiv). Upper-Bug floodplain-bog massive is protected [15].

Hydrologic regime. Among three main rivers of the studied area the Poltva River is most full-flowing with average unit discharge $6.16 \mathrm{l} / \mathrm{s} \cdot \mathrm{km}^{2}$ at the mouth near Busk. Lowest unit discharge is in the Solokia river $-4.07 \mathrm{l} / \mathrm{s} \cdot \mathrm{km}^{2}$ (Chervonohrad). The width of river bed is from $1-10 \mathrm{~m}$ in the upper part to $20 \mathrm{~m}$ in the lower part within the lowland of Male Polissia. The depth changes between 1.0 and $2.5 \mathrm{~m}$. The flow velocity fluctuates from $0.5-0.8 \mathrm{~m} / \mathrm{sec}$ within the highlands to $0.1-0.2 \mathrm{~m} / \mathrm{sec}$ within the lowland. The average river network density is $0.3-0.5 \mathrm{~km} / \mathrm{km}^{2}[2,12]$.

Alimentation of the rivers is mixed (rain, snow and underground). Hydrologic regime is characterized by high spring flood in abounded in water years, high summer or autumn rain flash floods, low summer-autumn water runoff in shallow years, and winter floods due to the thaws. During summer and autumn 2-6 floods can be observed. Average duration of the floods is $8-15$ days, maximal - 35 days. Water level usually rise up to 1.2-1.4 m sometimes to 2.5-3 m above " 0 ". Spring water levels are highest and can reach $5 \mathrm{~m}[7,12]$.

Water runoff of the rivers changes within wide limits (table 4). Along the rivers, this parameter decreases from 12.34 in headwaters to 4.99 (near Sokal). Average year water discharges fluctuate along the Western Bug river from $1.32 \mathrm{~m}^{3} / \mathrm{s}$ (near Sasiv) and $10-15 \mathrm{~m}^{3} / \mathrm{sec}$ (near Kamianka Buz'ka) to $31.21 \mathrm{~m}^{3} / \mathrm{s}$ (near Sokal). Year amplitudes during a year $-0.17-46 \mathrm{~m}^{3} / \mathrm{s}$ (near Sasiv) and $0.46-222 \mathrm{~m}^{3} / \mathrm{s}$ (near Kamianka Buz'ka). Absolute maximal discharge is $222 \mathrm{~m}^{3} / \mathrm{sec}$ in Kamianka Buz'ka and $230 \mathrm{~m}^{3} / \mathrm{sec}$ in Litovezh. Minimal discharges are observed on September - October and change along the river from 0.25 (near Sasiv) to $3.15 \mathrm{~m}^{3} / \mathrm{s}$ (near Sokal). In the abounded in water years with high winter temperatures the minimal discharges can amount $4.0 \mathrm{~m}^{3} / \mathrm{s}$ near Sasiv and $48 \mathrm{~m}^{3} / \mathrm{s}$ near Sokal.

Parameters of average water runoff for the long period.

Table 4 ередні $б$ г торічні пок зники стоку води

\begin{tabular}{|l|c|c|c|c|c|}
\hline \multicolumn{1}{|c|}{ River, town } & $\begin{array}{c}\text { Area, } \\
\mathbf{k m}^{\mathbf{2}}\end{array}$ & $\begin{array}{c}\text { Discharge, } \\
\mathbf{m}^{\mathbf{3}} \mathbf{/ s}\end{array}$ & $\begin{array}{c}\text { Runoff } \\
\text { volume, } \\
\mathbf{k m}^{\mathbf{3}}\end{array}$ & $\begin{array}{c}\text { Unit } \\
\text { discharge, } \\
\mathbf{l} / \mathbf{s} \cdot \mathbf{k m}^{\mathbf{2}}\end{array}$ & $\begin{array}{c}\text { Water } \\
\text { layer, } \mathbf{~ m m}\end{array}$ \\
\hline Bug, Sasiv & 107 & 1.32 & 0.04 & 12.34 & 389 \\
Bug, Kamianka Buz'ka & 2260 & 15.06 & 0.45 & 6.37 & 202 \\
Bug, Sokal & 6250 & 31.21 & 1.01 & 4.99 & 157 \\
Poltva, Bus'k & 1440 & 8.87 & 0.27 & 6.16 & 194 \\
Rata, Mezhyrichchia & 1740 & 8.05 & 0.26 & 4.63 & 146 \\
Solokia, Chervonohrad & 931 & 3.79 & 0.12 & 4.07 & 126 \\
\hline
\end{tabular}


In the long-term aspect, the cycles in water runoff dynamics are observed in whole area. Upper part of the Western Bug and the Poltva rivers are characterized by some increasing of water discharge in long-term period [7]. The main causes of long-term discharge fluctuations are the changes in precipitation and man-made factors in the basin. Seasonal discharge fluctuations besides climatic conditions are caused also by share of boggy lands, forests, water reservoirs, agro-technical measures in the catchments. Bigger part of water runoff is formed in summer-autumn period of the year. In shallow years, the share of winter period runoff increases (ground water alimentation). In abounded in water years the portion of spring runoff increases, and portion of summer-autumn period decreases. In the normal year share of spring water runoff is 40-60\%, winter period - 10-20\%.

Actual state of the drainage systems of Male Polissia. Most of the drained lands are located in the Western Bug river basin (260 000 ha, $50 \%$ of all drained area of the Lviv region). Drainage is done by open canals and closed drains networks. There were many deficiencies in drainage that caused somewhere excessive and somewhere insufficient dewatering effecting in ecological problems. Somewhere poor fertile lands were drained which should not to be used in agriculture. Another failure was drainage imperfection, noncomplexity. The best technology of two-side water regulation were implemented on $6.8 \%$ of area only. About $63 \%$ of the drained lands belong to the municipal property and local government, the Regional Water Management Department is owner of about $33 \%$. Most of drained fields become unprofitable. In consequence of agriculture reforms, the amount of drained land users has increased and land use structure has been changed as well. Central budget financial support of drainage systems exploitation has significantly decreased. The legislative and normative base for management, control, using and protection of the drainage systems is not satisfied. There are no motivations for investments in agriculture use of the drained lands. Many drainage systems of Lviv region are devoid of technical exploitation control and reconstruction or repairing works through some landowners and users fault. It caused worsening of the soils air-water regime and fertility and drainage systems technical state.

According to the Hydrogeologic-meliorative Expedition, the acidity of dewatered soils increases. Especially significant increasing of the high acidity areas is observed in podzolic soils. The main cause of acidization is lack of lime manuring and fertilizing by the acid manures like nitrogen fertilizers. Many drained fields are devoid of cultivating and overgrow by weed and bushes.

There are many drainage systems with unsatisfactory technical state, which are not able to water regulating. They demand repairing, reconstruction and modernization. Practicability of these measures needs the detail and complex investigations and scientific and economical substantiation. The first step of their implementation is detail inventory of the drainage systems.

In the Male Polissia, there are three etalon drainage systems: "Solokia", "Bolodurs'ka" and "Nedilchyns'ka". Etalon drainage systems are objects of background monitoring which provide ecological information about the meliorative state of the drained lands.

Meliorative state of the drained lands reflects stable relations between combined influences of complex factors and allows evaluating the applicability of the drained lands for agriculture. The state assessment is done by comparing of the real state parameters with evaluation criteria.

Under drainage effect, the amplitude of groundwater level fluctuation is close to the drainage norm $(60-90 \mathrm{~cm})$. The most intensive water level decreasing is observed during first 
three years after dewatering. Later the water level becomes stable and fluctuated due to meteorological conditions only.

There is three degrees gradation of the meliorative state of the drained lands: favorable, satisfactory and unsatisfactory with according groundwater levels. Favorable state is characterized by the water level between 0.75 and $1.5 \mathrm{~m}$ depending on soil type and crops, satisfactory $-0.5-0.75$ and $1.5-2.0 \mathrm{~m}$ and unsatisfactory - upper 0.5 and lower $2.0 \mathrm{~m}$. Satisfactory state testifies that cultivating is possible on the assumption of improving measures implementation. Unsatisfactory state designates inexpediency of cultivation on the drained fields.

Meliorative state of the drainage systems. Solokia drainage system is located on the sandr-alluvial plain of the Rata river basin in the western part of Male Polissia. Quaternary sediments occur everywhere and are presented by alluvial-deluvial sands, loamy sands and loams of 7-15 m. On the floodplain peats of 2-4 $\mathrm{m}$ are spread on the marl weathering crust.

The system was established in 1972 and reconstructed in 1983-1989. The area is 16236 ha. The distance between canals is $200-300 \mathrm{~m}$, between drains $-10-14 \mathrm{~m}$. Open canals occupy 8481 ha, closed drains -7755 ha (about $30 \%$ ). Two-side water regulation is implemented on $2874 \mathrm{ha}$. The total length of dewatering network is $6147 \mathrm{~km}$, including $5562 \mathrm{~km}$ of drains and $584 \mathrm{~km}$ of the canals. Dewatering norm is $0.8-1.1 \mathrm{~m}$.

The land use structure is following: arable lands -4279 ha $(28 \%)$, perennial plants 31 ha $(0.2 \%)$, pasture lands -4546 ha $(29 \%)$, hayfields -6476 ha (42\%), other lands 148 ha $(0.8 \%)$. About $36-42 \%$ of the area is occupied by peats (5 878 ha), $9 \%$ - sandr sands and loamy sands (1 $468 \mathrm{ha}$ ), $32 \%$ - light loams (5 215 ha), $23 \%$ - loams (3 675 ha).

Impact of dewatering upon groundwater levels. Comparing of average year water levels was done for the years with mean procurement of water (many years average precipitation). According to the table 5, the groundwater levels have decreased on $0.26-2.23 \mathrm{~m}$ due to dewatering. According to geomorphologic elements of the Solokia river valley, there are three regimes of the groundwater level: floodplain, terrace and slope. Groundwater level regime has two kinds: first one, when Quaternary and Cretaceous aquifers are interrelated, and second, when they are isolated each other.

After dewatering of interrelated aquifers by the floodplain regime type the water level decreasing is equal $1.15 \mathrm{~m}$ for Quaternary and $0.81 \mathrm{~m}$ for Cretaceous aquifers. At the isolated aquifers of the floodplain regime, the Quaternary water level has decreased on 1.89-2.23 m, the Cretaceous one $-0.6 \mathrm{~m}$. The range of water level changes is $2.5 \mathrm{~m}$ for Quaternary and $0.9 \mathrm{~m}$ for Cretaceous aquifer.

The groundwater level fluctuation curves for the terrace regime type by the interrelated aquifers are similar to the floodplain one. Nevertheless, the amplitudes are higher. The groundwater level decreasing after dewatering is equal $0.4 \mathrm{~m}$ for both aquifers, Quaternary and Cretaceous. The curves for the isolated Quaternary and Cretaceous aquifers by the terrace type are quite different. The levels of the Quaternary aquifer are characterized by leap fluctuations with maximum in spring and minimum in winter. The Cretaceous one is characterized by smooth variation with slight summer increasing. After dewatering the Quaternary aquifer water level has decreased on $0.76 \mathrm{~m}$, the Cretaceous water level - on $0.3-0.35 \mathrm{~m}$.

The slope type of the regime is characterized by leaps of water levels which fast react on precipitation. The water level decreasing amounts $0.2-0.3 \mathrm{~m}$. 
ISSN 2078-6441. Вісник Львівського університету. Серія географічна. 2018. Випуск 52

Comparing characteristics of average annual groundwater levels before and after dewatering [9] ередньорічні рівні грунтових вод до і після осушення [9]

\begin{tabular}{|c|c|c|c|c|c|c|c|c|c|}
\hline \multirow[b]{3}{*}{ 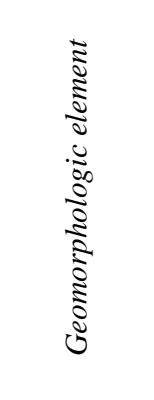 } & \multirow[b]{3}{*}{ 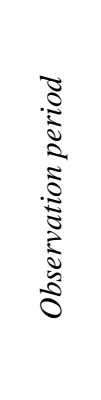 } & \multicolumn{8}{|c|}{ Cross-sections } \\
\hline & & \multicolumn{2}{|c|}{$I X$} & \multicolumn{2}{|c|}{$X$} & \multicolumn{2}{|c|}{$X I V$} & \multicolumn{2}{|c|}{$X V$} \\
\hline & & 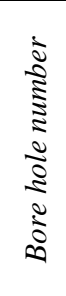 & 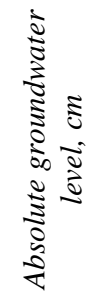 & 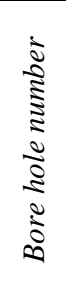 & 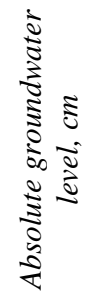 & $\begin{array}{l}\grave{\Xi} \\
\vdots \\
\vdots \\
\Xi \\
\Xi \\
0 \\
0 \\
0\end{array}$ & 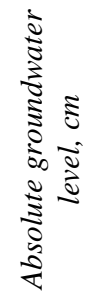 & 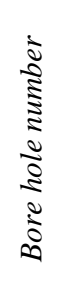 & 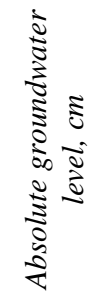 \\
\hline \multirow{6}{*}{ Floodplain } & Before & 75 & 198.24 & 44 & 196.93 & 115 & 204.08 & 101 & 200.99 \\
\hline & After & 120 & 197.43 & 147 & 196.34 & 179 & 202.19 & 203 & 109.93 \\
\hline & Before & 76 & 198.12 & & & 116 & 204.75 & & \\
\hline & After & 126 & 196.97 & & & 190 & 202.52 & & \\
\hline & Before & 78 & 198.57 & & & & & & \\
\hline & After & 129 & 197.63 & & & & & & \\
\hline \multirow{2}{*}{ First terrace } & Before & 73 & 198.36 & & & 114 & 203.70 & & \\
\hline & After & 116 & 197.60 & & & 202 & 203.30 & & \\
\hline \multirow{2}{*}{ Slope } & Before & 72 & 198.29 & & & & & & \\
\hline & After & 111 & 198.03 & & & & & & \\
\hline
\end{tabular}

The seasonal variation of groundwater level. Groundwater level monitoring in the Solokia drainage system is carried out by the Lviv Hydrogeological-meliorative Expedition in 52 bore holes on 5 cross-sections (including three etalon cross-sections IV, and XIII) and core bore holes number 22, 26, 171, 173, 224, 234 located near Murovane village, Uhniv and Chervonohrad towns.

Seasonal variation analysis has been done by the data observed during last 10 years on three etalon cross-sections including 45 bore holes. For every cross-section the graphs have been created by the average monthly groundwater level in the bore holes (fig. 1-6). Obviously, in all bore holes of the cross-section IV the maximal water level is observed in May and the minimal - in October - November. The amplitudes amount 0.2-0.5 m. In the cross-section XII maximal levels are in May and April (bore hole 233-A), the minimal water levels are observed in October, November, locally August but in some bore holes the minimums are in winter, February, January (fig. 4). The amplitudes amount $0.2-0.6$ except 233-A with slope type regime. The most stable water level regime is characteristic for the cross-section XIII, where amplitudes $0.2-0.4 \mathrm{~m}$ dominate except number 165 where range is equal 0.6. The seasonal variations are similar to other cross-sections.

During last years, the favourable groundwater level $(0.75-1.25 \mathrm{~m})$ was observed on $51 \%$ of the Solokia drainage system area. Unsatisfactory groundwater level has been observed on the area of 254 ha.

The total area with optimal soil water reserve amounts 14712 ha (90.61\%), with insufficient soil water reserve -1270 ha $(7.82 \%)$ and excessive -254 ha $(1.57 \%)$. By the 
soil acidity the alkaline reaction was observed on the area of 8999 ha $(55.43 \%)$, neutral 5587 ha $(34.41 \%)$, acid - 1650 ha $(10.16 \%)$.

By the erosion processes development favourable state is observed on the area of 15911 ha, satisfactory - on 305 ha, unsatisfactory - on 25 ha area. Unsatisfactory state is caused by suffosion due to mining activity.

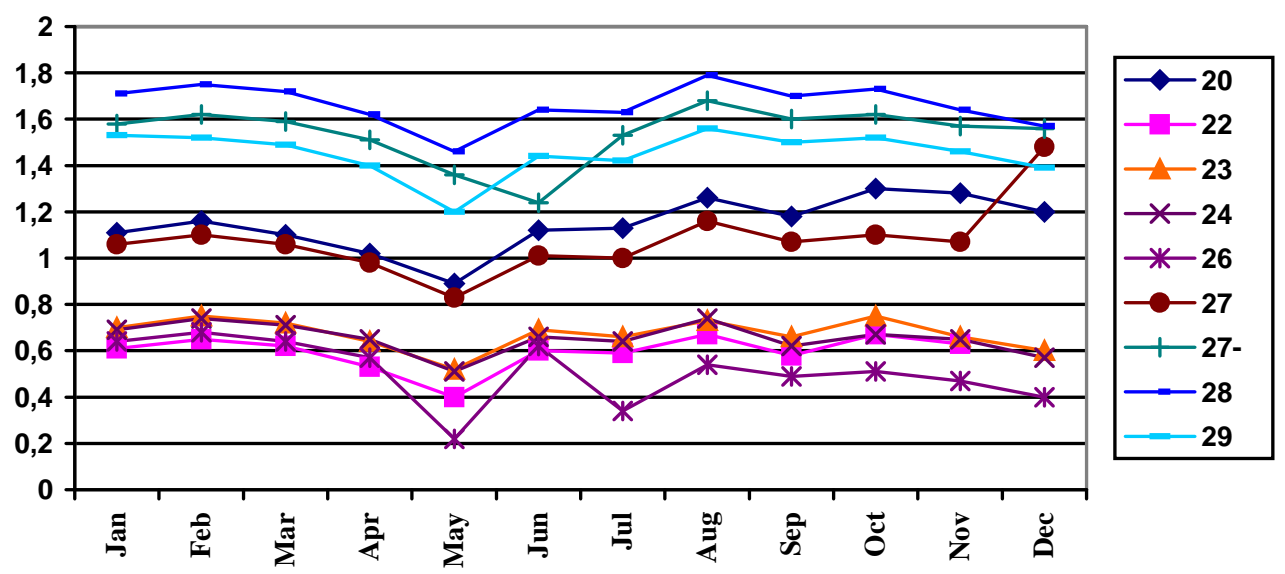

Fig. 1. Average monthly groundwater level on the cross-section IV ис. 1. ередньомісячний рівень грунтових вод у спостережному створі IV
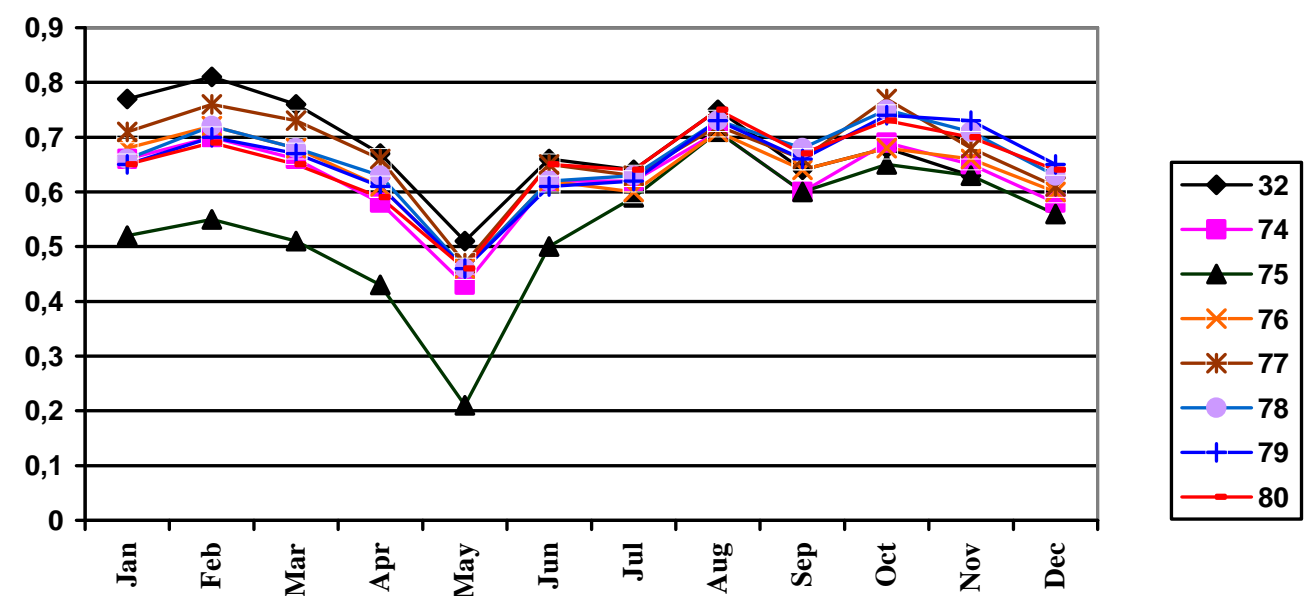

Fig. 2. Average monthly groundwater level on the cross-section IV (continuing) ис. 2. ередньомісячний рівень грунтових вод у створі IV (продовження) 


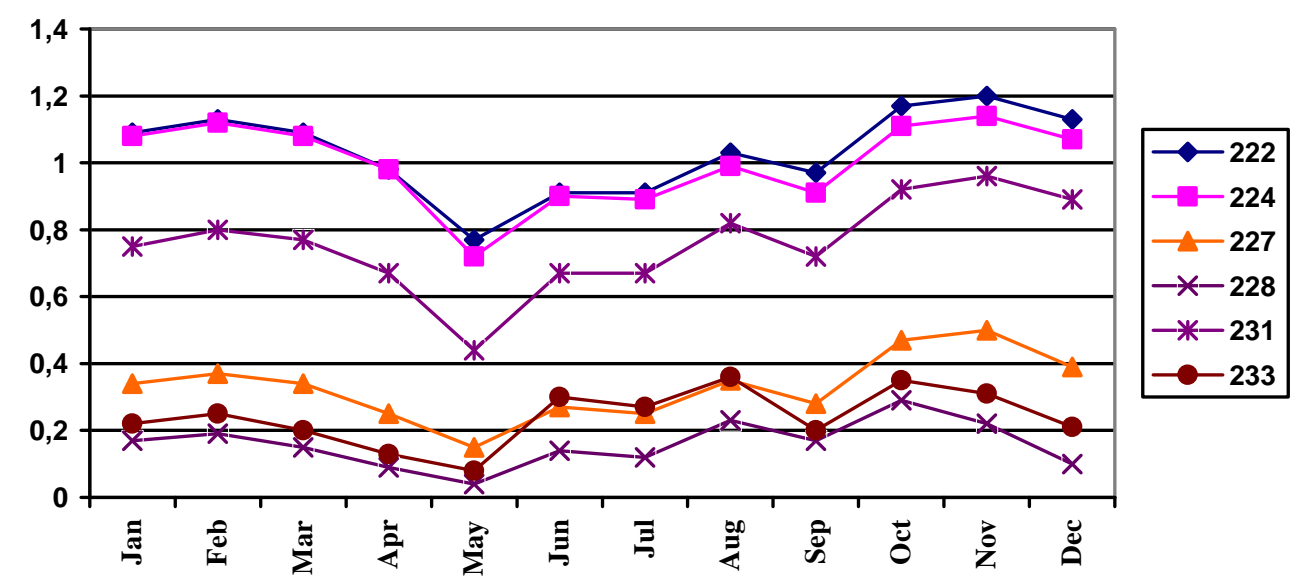

Fig. 3. Average monthly groundwater level on the cross-section XII ис. 3. ередньомісячний рівень грунтових вод у спостережному створі

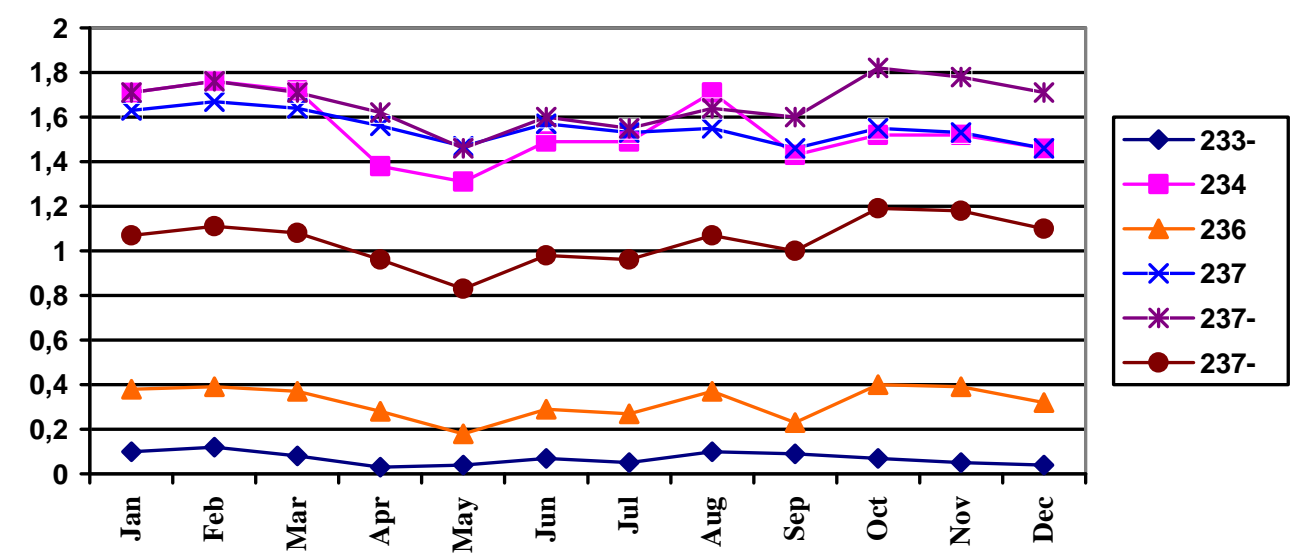

Fig. 4. Average monthly groundwater level on the cross-section XII (continuing) ис. 4. ередньомісячний рівень грунтових вод у створі (продовження)

Another etalon drainage system - Bolodurs'ka - is situated on the Brody outwash-alluvial plain in the north-east most watered part of the Male Polissia. The main water accepter is the Bolodurka river. Total area of the system is 3869 ha. 2706 ha is dewatered by the open canals and 1163 ha - by the drains. Two side dewatering is implemented on 707 ha area. The system area is composed of the peats (2 507 ha $-61 \%)$, sandy and loamy sandy soils (1 315 ha $-34 \%$ ), loamy soils (193 ha $-5 \%$ ). The land use structure is following: arable lands - 581 ha $(15 \%)$, perennial plants -15 ha $(0.4 \%)$, pasture lands -1031 ha $(26.6 \%)$, hayfields -1425 ha $(37 \%)$, other lands -817 ha $(21 \%)$. 


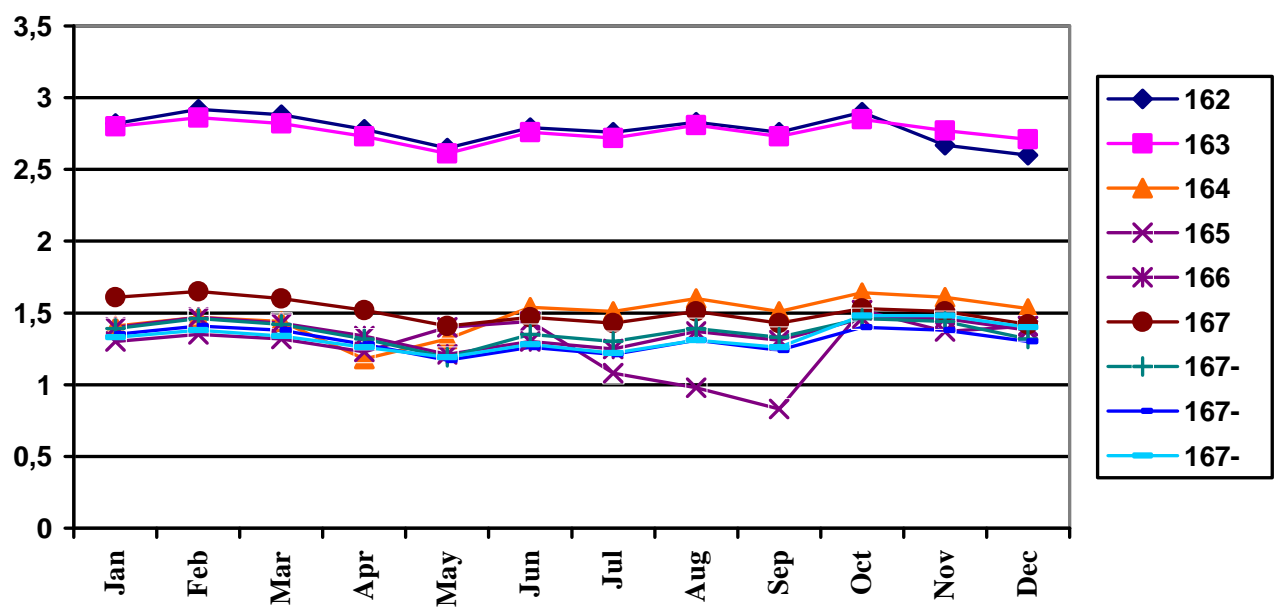

Fig. 5. Average monthly groundwater level on the cross-section XIII ис. 5. ередньомісячний рівень грунтових вод у спостережному створі

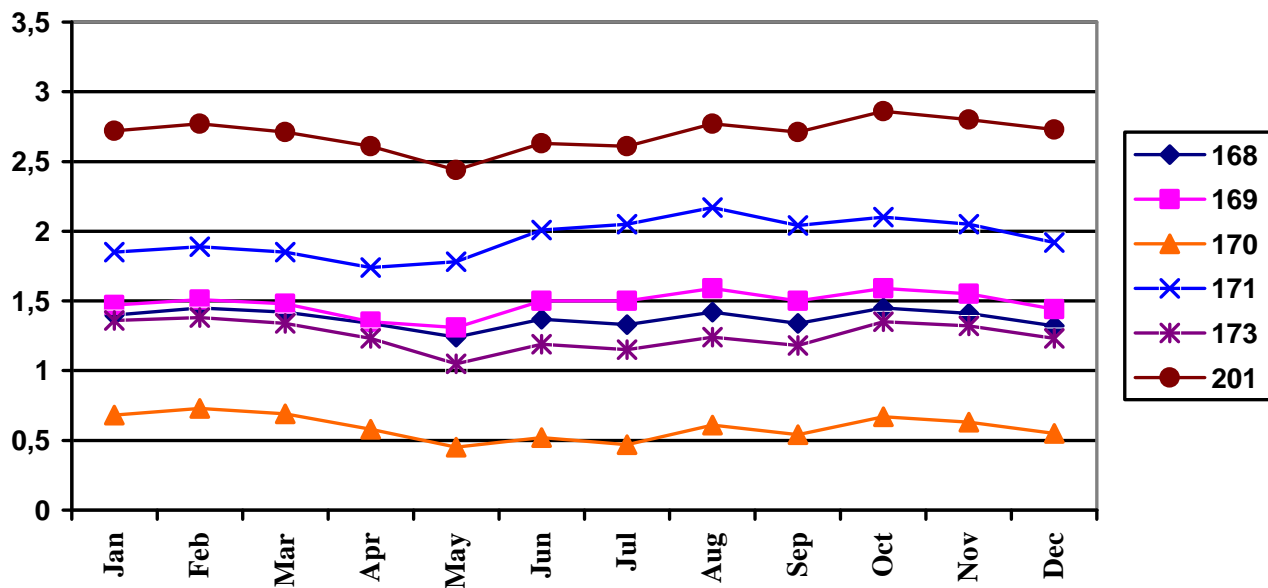

Fig. 6. Average monthly groundwater level on cross-section XIII (continuing) ис. 6. ередньомісячний рівень грунтових вод у створі (продовження)

Nedilchyns'ka etalon drainage system is located in the southern part of Male Polissia, within the Ridge Pobuzhzhia. Alternate of the flat interfluve ridges and the slow-flow valleys of the Polissia type present the relief here. Superwatering of this territory is caused by high groundwater levels combined with significant slope water runoff within the deluvial interfluves. The total area of the drainage system amounts 1767 ha. Closed drains network 
ISSN 2078-6441. Вісник Львівського університету. Серія географічна. 2018. Випуск 52

covers 967 ha, open canals dewater 800 ha of the area is drained Two side drainage accounts 762 ha. This drainage system is composed of the peats $(40 \%)$ and the loamy soils $(60 \%)$. Quarter of the peats is silted or buried.

Meliorative state of the Solokia drainage system on $36.40 \%$ of the area is classified as favorable. There is trend to increase of this area during last decade due to clearing of the drainage canals. Unsatisfactory meliorative state is characteristic for $1.6 \%$ of the area. Meliorative state of the Nedilchyns'ka and Bolodurs'ka drainage systems is mostly satisfactory and favourable for cultivating.

Summary parameters of the analyzed drainage systems are presented in the table 6.

Aggregate parameters of the etalon drainage systems of the Male Polissia according to data of the Lviv Hydrogeological-meliorative Expedition

ведені пок зники ет лонних осушних систем лого олісся згідно з д ними ьвівської гідрогеолого-меліор тивної експедиції

\begin{tabular}{|c|c|c|c|}
\hline \multirow{2}{*}{ Parameters } & \multicolumn{3}{|c|}{ Drainage system } \\
\hline & Solokia & Nedilchyns'ka & Bolodurs'ka \\
\hline Area, ha & 16236 & 1767 & 3869 \\
\hline \multicolumn{4}{|c|}{ Groundwater level, \% } \\
\hline$<0.5 \mathrm{~m}$ & 0.13 & 0.20 & 0.23 \\
\hline $0.5-0.75 \mathrm{~m}$ & 25.57 & 3.40 & 13.13 \\
\hline $0.75-1.25 \mathrm{~m}$ & 38.20 & 44.40 & 48.06 \\
\hline $1.25-1.50 \mathrm{~m}$ & 26.79 & 23.70 & 39.89 \\
\hline $1.50-1.75 \mathrm{~m}$ & 9.18 & 20.90 & 6.43 \\
\hline $1.75-2.00 \mathrm{~m}$ & 0.10 & 7.00 & 1.03 \\
\hline $2.00-3.00 \mathrm{~m}$ & - & 0.10 & 0.23 \\
\hline \multicolumn{4}{|c|}{ Soil acadity $p, \%$} \\
\hline Alkaline $(\mathrm{p}>6.5)$ & 55.43 & 92.70 & 51.70 \\
\hline Neutral (pH 5.5-6.5) & 34.41 & 7.30 & 25.80 \\
\hline Acid $(\mathrm{pH}<5.5)$ & 10.16 & - & 22.50 \\
\hline \multicolumn{4}{|c|}{ Soil water reserve in $0,5 \mathrm{~m}$ of the profile, $\%$} \\
\hline Optimal & 90.61 & 58.10 & 92.06 \\
\hline Insufficient & 7.82 & 23.80 & 7.70 \\
\hline Excessive & 1.25 & 18.10 & 0.24 \\
\hline \multicolumn{4}{|c|}{ Meliorative state, \% } \\
\hline Favourable & 36.40 & 44.00 & 92.07 \\
\hline Satisfactory & 62.00 & 55.90 & 7.70 \\
\hline Unsatisfactory & 1.60 & 0.10 & 0.23 \\
\hline
\end{tabular}

Next stage of the drainage systems ecological and meliorative state investigations in the Lviv region is determining and evaluation of the environmental and biological value of the drained areas, biodiversity analysis, assessment of the degradation degree and man-made changes of the biocoenoses, and evaluation of the opportunity and practicability of the renaturalization. 
1. одно-болотні угіддя кр їни / ред. . рушевського, . рук. иїв : орноморськ прогр м Wetlands International, 2006. 312 с.

2. еогр фічн енциклопедія кр їни / едкол.: . ринич (відп. ред.) т ін. иїв, 1990. . .2. . 36 .

3. кологічний моніторинг регіону: експертн оцінк ст ну і функціонув ння / ред. . ов льчук . ьвів : ук.-вид. центр “ пілля- ”, 2009. 608 с.

4. кологія водно-болотних угідь і торфовищ: збірник н укових ст тей / гол. ред. . оніщук. иїв : “нтерсервіс", 2014. 300 с.

5. $\quad$ iн $m$., $у р н є в$. емпер турний режим повітря і грунту в кр їні. ьвів, 2001. $800 \mathrm{c}$.

6. ов льчук . егіон льний еколого-геоморфологічний н ліз. иїв, 1997.440 с.

7. ов льчук ., ург невич ., ихнович . ідрологічний н ліз б сейнової системи хідного угу // ідрологія, гідрохімія і гідроекологія / відп. ред. ільчевський. иїв- уцьк, 2002. . 4. . 89-100.

8. озловський . сушення земель хідної кр їни: історія т суч сний ст н н укових досліджень // одне господ рство кр їни. 2001. № 1-2.

9. озловський . мін гідрогеолого-меліор тивних умов в долині р. олокії під впливом осушення // ит ння меліор ції і ефективного використ ння осушених земель кр їнського олісся. ьвів : ищ школ , 1976. . 80-85.

10. озловський ., ілоус ., огут ., евців . ро деякі результ ти досліджень умов формув ння стоку т його хімічного скл ду н осушув них землях з хідного регіону кр їни // ідрологія, гідрохімія і гідроекологія. . : ік - ентр, 2000. . 1. .122-127.

11. слов ., ин ев . елиор ция и охр н природы. . : оссельхозизд т, 1985. $271 \mathrm{c}$.

12. рирод ьвівської обл сті / ред. . еренчук . ьвів, 1972. 152 с.

13. ись . еоморфологія - ьвів : ид-во ьвів. ун-ту, 1962. 224 с.

14. вор $\kappa$. ен тур ліз ція земель, неефективних для господ рського використ ння // уковий вісник олинського н ціон льного університету імені есі кр їнки. ер. ізичн геогр фія. 2010. ип. 14. . 32-35.

15. Korytarz ekologiczny doliny Bugu: Stan, zagrozhenia, ochrona: Praca zbiorowa pod red. A. Dombrowskiego, Z. Glowackiego, W. Jakubowskiego, I. Kovalchuka, Z. Michalczyka, M. Nikiforova, W. Szwajgiera, K. Wojciechowskiego. Warszawa : Fundacja IUCN Poland, 2002. $350 \mathrm{~s}$.

\section{REFERENCES}

1. Marushevs'kyi, H., \& Zharuk, I. (2006). Peat lands of Ukraine. Kyiv: Black Sea Program Wetlands International, 312 p. (in Ukrainian).

2. Marynych, O. (Ed.) (1990). Geographic Encyclopedia of Ukraine, 2. Kyiv, 36 (in Ukrainian).

3. Kovalchuk, I. (Ed.) (2009). Environmental monitoring of the region: Expert assessment of state and functioning. Lviv, 608 p. (in Ukrainian).

4. Konishchuk, V. (Ed.) (2014). Ecology of wetlands and peat lands. Kyiv, 300 p. (in Ukrainian). 
5. Kinash, R., \& Burnayev, O. (2001). Temperature regime of the air and soils in Ukraine. Lviv, 800 p. (in Ukrainian).

6. Kovalchuk, I. (1997). Regional environmental-geomorphologic analysis. Kyiv, 440 p. (in Ukrainian).

7. Kovalchuk, I., Kurhanevych, L., \& Mykhnovych, A. (2002). Hydrologic analysis of the Western Bug River system. Hydrology, hydrochemistry and hydroecology, 4. KyivLuts'k, 89-100 (in Ukrainian).

8. Kozlovs'kyi, B. (2001). Dewatering in Western Ukraine: History and nowadays of the research. Water management of Ukraine, 1-2 (in Ukrainian).

9. Kozlovs'kyi, B. (1976). Hydrogeologic and meliorative conditions changes in the Solokia river valley under dewatering. Problems of melioration and effective using of drained lands of Ukrainian Polissia (pp. 80-85). Lviv, Vyshcha Shkola (in Ukrainian).

10. Kozlovs'kyi, B., Bilous, Y., Kohut, N., \& Shevtsiv, Y. (2000). Some results of water runoff forming conditions and chemical composition research on the drainage lands of Western Ukraine. Hydrology, hydrochemistry and hydroecology, 1, Kyiv, 122-127 (in Ukrainian).

11. Maslov, B., \& Minaev, I. (1985). Melioration and environment. Moscow, Rosselkhozizdat, 271 p. (in Russian).

12. Herenchuk, K. (Ed.). (1972). Nature of Lviv region. Lviv, Lviv University Pub., 152 p. (in Ukrainian).

13. Tsys', P. (1962). Geomorphology of Ukrainian SSR. Lviv, Lviv University Pub., 224 p. (in Ukrainian).

14. Shvorak, A. (2010). Renaturalization of not effective lands for agricultural use. Visnyk of the Lesia Ukrainka National Volynian University. Series Physical Geography, 15, 32-35 (in Ukrainian).

15. Dombrowski, A., Glowacki, Z., Jakubowski, W., Kovalchuk, I., Michalczyk, Z., Nikiforov, M., Szwajgier, W., \& Wojciechowski, K. (Ed.). (2002). Korytarz ekologiczny doliny Bugu: Stan, zagrozhenia, ochrona. Warszawa, Fundacja IUCN Poland, 350 pp. (in Polish).

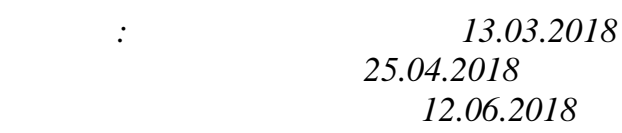

ндрій ихнович

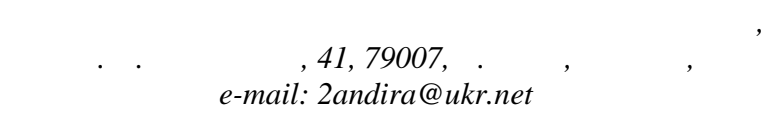

уч сні проблеми землекористув ння і рен тур ліз ції н осушених землях свідч ть про суттєве зменшення продуктивності грунтів, перев жно вн слідок їхнього неефективного використ ння і нез довільного технічного ст ну осушних систем. болочені т перезволожені землі в окремих р йон х ьвівської обл сті з йм ють до 80-90\% території і предст влені великими суцільними м сив ми у річкових 6 сейн х. сьогодні більшість осушних систем х р ктери- 
зуються нез довільним технічним ст ном, втр тили бо втр ч ють свої водорегуляційні можливості і сільськогоспод рське зн чення. тож, дослідження суч сного меліор тивного т екологічного ст нів осушених земель, технічного ст ну осушних систем 3 визн ченням н йпріоритетніших територій для рен тур ліз ції з болочених земель $€$ кту льним і в жливим н уковим i пр ктичним з вд нням. ого викон ння є неможливим без обгрунтув ння н укової концепції і методик т ких досліджень. сушні системи оліської ч стини ьвівської обл. перебув ють в центрі фокусі ув ги у цьому дослідженні. етою роботи є оцінк ст ну осушних систем, вст новлення прид тності осушених територій для рен тур ліз ції, т кож обгрунтув ння т д пт ції методик оцінюв ння еколого-меліор тивного ст ну осушених земель. окрем , висвітлено пит ння історії створення т експлу т ції меліор тивних осушних систем у північній ч стині ьвівської обл., особливостей дослідження їхнього технічного т еколого-меліор тивного ст нів. редст влено основні пок зники і перелік осушних систем у оліській ч сині ьвівщини, систему моніторингу їхнього ст ну, методику і критерії оцінюв ння еколого-меліоp тивного ст ну. озглянуто влив осушення н режим рівнів підземних вод, про н лізов но їхню сезонну дин міку в меж х осушної системи олокія. изн чено меліор тивний ст н трьох ет лонних осушних систем у різних ч стин $\mathrm{x}$ лого олісся.

лючові слов : осушні системи, відведення вод, меліор тивний, екологічний і технічний ст ни, рен тур ліз ція. 